\title{
A brief biography of António Ferreira da Silva: The most remarkable Portuguese chemist of the $19^{\text {th }}$ century
}

\author{
Paulo Nuno Martins* \\ INew University of Lisbon, Portugal \\ Received: 眥April 16, 2018; Published: 眥April 26, 2018 \\ *Corresponding author: Paulo Nuno Martins, Interuniversity Center for History of Science and Technology, Building VII, Floor 2, 2829- \\ 516 Caparica, Portugal, E-mail: paulonunom@gmail.com
}

\begin{abstract}
António Ferreira da Silva was the most remarkable Portuguese chemist of the XIX century. In this short essay, I will describe the most important milestones of his life, particularly the main works performed by him in the field of chemistry.

Keywords: Scholar of chemistry, Society of Instruction of Oporto, Municipal laboratory of chemistry of Oporto, Journal of Pure and Applied Chemistry (Portuguese Society of Chemistry).
\end{abstract}

\section{Introduction}

António Joaquim Ferreira da Silva was born on $28^{\text {th }}$ July 1853 , in one of the cells that existed in the Convent of S. Martinho, in Cucujães, Oliveira de Azeméis. He was the son of António Joaquim Ferreira da Silva and Margarida Emília Ferreira da Silva [1].

In 1865, after completing his primary studies, António Silva moved to the city of Oporto where he completed his high school studies. In 1870-1871, he studied some subjects about science in the Polytechnic Academy of Oporto and Industrial Institute of Oporto, as well as some subjects on theology in the Seminary of Oporto. In 1876, he completed the bachelor's degree in Natural Philosophy at the University of Coimbra and in the following year, he presented a thesis entitled "Study on chemical classifications of organic compounds" [2] at the Polytechnic Academy of Oporto.

In 1880, António Ferreira da Silva left for Brazil in order to get married with a second cousin named by Idalina de Sousa Godinho with whom had 14 children. Idalina Godinho was the daughter of Viscount of Santiago de Riba-UI who greatly helped António Ferreira da Silva during his studies. In 1880, António Ferreira da Silva was one of the founding members of the Society of Instruction of Oporto (1880-1889) which had as main purpose to promote the development of the different branches of science due to the great demographic growth, economic and cultural development that occurred in Portugal in the ends of $19^{\text {th }}$ century [3]. Still in 1880, the City Hall of Oporto asked António Ferreira da Silva to analyze the waters of the river Sousa. In this regard, he has written a
Report entitled "On the waters of the river Sousa and the springs and fountains of the city of Oporto" [4] which provoked a strong controversy at the time, due to the results obtained in the chemical analyzes.

In 1882, António Ferreira da Silva was invited to install the Municipal laboratory of chemistry of Oporto and, in the following year, he became director of this laboratory. It was in this laboratory that António Silva held most of his research work, having written several papers in the field of chemistry [5]. In fact, from 1877 to 1884, António Silva acquired the chemical skills in this laboratory that contributed to make him the most remarkable Portuguese chemist of the $19^{\text {th }}$ century (and beginning of the $20^{\text {th }}$ century). Thus, in 1884, the famous chemists Wurtz and Friedel have proposed to member of the Chemical Society of Paris. António Ferreira da Silva also belonged to the Chemical Society of Belgium, the Chemical Society of Italy, the American Chemical Society, among others. António Ferreira da Silva also represented the Portuguese chemistry in several congresses, such as, Vienna, Paris, Rome and London [6].

António Ferreira da Silva was both a researcher and scholar in the field of chemistry [7]. In fact, António Ferreira da Silva contributed to the development of the chemical science through the experiments in the Municipal laboratory of Oporto and by teaching at the Polytechnic Academy of Oporto (later named by Faculty of Sciences of Oporto) and School of Pharmacy of Oporto [8]. 
In this regard, from 1884, António Ferreira da Silva taught the discipline of Organic Chemistry and Analytical at Polytechnic Academy of Oporto [9]. Between 1902 and 1911, António Ferreira da Silva taught the discipline of Legal Chemistry and Health at the School of Pharmacy of Oporto. In 1918-1919 and 1922-1923, he taught the discipline of Toxicology at the Faculty of Medicine of Oporto. António Ferreira da Silva wrote some technical books [10], such as, "Elementary Chemical Treaty" and "Elements of analytical and organic chemistry". I should also mention that António Ferreira da Silva got a PhD, in 1918, in physical-chemical Sciences at Faculty of Sciences of Oporto, as well as a PhD, in 1922, in pharmaceutical Sciences at the School of Pharmacy of Oporto.

In 1905, António Ferreira da Silva began with the publication of a series of annotations about chemistry in the magazine entitled Magazine of Pure and Applied Chemistry (nowadays called by «Magazine of Chemistry»). In some of these notes, on chemical Nomenclature, António Ferreira da Silva has explained the etymology and the roots of the chemical name of the several organic compounds [11]. In general, the high quality of the chemical articles written made this magazine a "benchmark" for all Portuguese chemistry. For this reason, it became the official magazine of the Portuguese Chemical Society which was also founded by António Ferreira da Silva, in 1912.

António Ferreira da Silva won several awards such as, for example, in 1885, the commend of the Order of St. James of Scientific and Literary Merit. In 1882, he was also appointed as Knight of the Military Order of our Lady of Conception (at Vila Viçosa) and, in 1908, as Knight of the Legion of Honour of the Chemical Society of Paris. He was also a member of the Academy of Sciences of Lisbon and vice-Rector of the University of Oporto between 16th February 1918 and $29^{\text {th }}$ October 1921 [12].

António Ferreira da Silva died on $23^{\text {rd }}$ August of 1923, in his house of Lameiro, in Figueiredo, in Santiago de Riba-UI. The body was taken to the cemetery of Cucujães, where he was buried in the next day.

\section{Methods}

In this short communication about the biography of António Ferreira da Silva, I collected and analyzed the main scientific books and technical articles, in this area of study, that area available in academic libraries. Thus, I selected the 22 most important items, based on the "impact factor" of the article and the "reference" books on this topic in order to be useful to the reader who aims to have just an idea of this subject, maintaining the scientific rigor of my research.

\section{Results and Discussion}

In this section, I will present the results and the most relevant facts of my research about the António Ferreira da Silva's most important works on chemistry. In fact, the most important part of the work of António Ferreira Silva was in the field of chemistry applied to the pharmaceutical chemistry, forensic toxicology, industrial chemistry and chemical reactions.

In the field of pharmaceutical chemistry, António Ferreira da Silva discovered new reactions for the analysis of alkaloids, such as in the papers entitled "Sur une nouvelle reaction de la cocaine" [13], "Sur l'emploi du sulfosélénite d'ammoniaque pour caracteriser les alcalóides" [14], "Sur une nouvelle reaction de l'éserine et une matiére verte derivèe du même alcalóide" [15] that were published by the Academy of Sciences of Paris. For this reason his name stayed connected to the chemical reaction named by "Ferreira da Silva", as well as the chemical reagent named by "Lafont and Ferreira da Silva".

Between 1890 and 1893, in the field of toxicology and forensic chemistry [16], António Ferreira da Silva reached international recognition in the scientific world due to the famous case of Vicente Urbino de Freitas (1849-1913) who was accused of having poisoned with various alkaloids his wife's family members, through chemical analysis made by António da Silva showed that Vicente de Freitas was not innocent. In this regard, in 1889, he was appointed as chemist-analyst and member of the medical Council of Oporto.

In 1894, in the field of industrial chemistry, I should refer his researches about the allegations of "existence of salt" in Portuguese wines [17]. In fact, António Ferreira da Silva published a work entitled "Sur une cause d'erreur dans la recherche de l'acide salicylique dans les vins Portugais" that were presented in the Academy of Sciences of Paris and they had great impact in the Portuguese economic development due to high exports of Portuguese wines to Brazil. This episode contributed to the increase of António Ferreira da Silva's prestige that led to the award with the title of Majesty's Counsel, honorary member of the Trade Association of Oporto and the Central Association of Portuguese Agriculture. António Ferreira da Silva also presided to the Commission of Studies and Unification of the Methods of Analyzes of wines, olive oils and vinegars, in Portugal (1895-1902).

In the field of chemical reactions, António Ferreira da Silva followed the scientific development that has occurred internationally in this area of knowledge, in the late $19^{\text {th }}$ century. In this regard, he had a connection with the chemist Berthelot with whom established a deep friendship and discussed various subjects related to organic chemical reactions, such as acetylene and the metallic acetylets that are described in the following papers: "Sur la constitution des carbonyles métalliques" [18], "Sur la réfraction des metaux atomique dans les carbonyles métalliques et les formules de ces constitution derives" [19] and "Sur la Constitution des dérivés l'acétylène métalliques, et sur l' acétylène comme lien entre la chimie minérale et la chimie organique" [20].

Finally, I should refer the research works done by António Ferreira da Silva in the History and Philosophy of Science area. For example, in his speech entitled «the importance and dignity of science», he referred to the importance of the pedagogical work of 
the scholar in the complete training of the students (humanistic and scientific) [21].

\section{Conclusion}

António Ferreira da Silva was, arguably, the most distinguished Portuguese chemist of the $19^{\text {th }}$ century (and beginning of the 20th century). However, at the end of his life, due to Parkinson's disease, António Ferreira da Silva decreased his intense professional activity [22]. And so, he taught only a few subjects on chemistry in the courses in the Industrial Institute and School of Pharmacy of Oporto, as well as some sporadic publication of articles in «Magazine of Pure and Applied Chemistry».

In 1922, friends, admirers and disciples provide a fair tribute to his scientific work, through the inauguration of his bust in bronze and the creation of an annual award entitled "Ferreira da Silva" to the best student in chemistry, in Portugal, as well as the assignment of his name «Ferreira da Silva» to the chemical laboratory of the Faculty of Sciences of Oporto.

\section{References}

1. Archives of Faculty of Sciences of Oporto, António Ferreira da Silva file.

2. António F da Silva (1877) Estudo sobre as Classificações Químicas dos Compostos Orgânicos. Academia Politécnica do Porto.

3. Duarte N Cardoso (2003) Sociedade de Instrução do Porto (1880-1889). Estudos \& Documentos, Douro 16: 123-152.

4. António F da Silva (1881) As águas do rio Sousa e os mananciais e fontes da cidade do Porto. Relatório da Câmara Municipal do Porto.

5. Jorge F Alves, Rita C Alves, Ferreira da Silva e o (1884-1917) Laboratório Químico Municipal do Porto. História da Saúde-Estudosdo Século XX, Imprensa da Universidade de Coimbra, 2012, №12.

6. Jorge F Alves, Rita C Alves, AJ Ferreira da Silva (2013) nos caminhos da química, Universidade do Porto.

7. Rodrigo G de Carvalho (1998) História do Ensino da Engenharia Química na Universidade do Porto, Faculdade de Engenharia da Universidade do Porto.
8. António F da Silva (1893) Breve Notícia sobre o ensino da Chimica na Academia Polytechnica do Porto, Porto, Portugal.

9. Paulo N Martins (2017) Organic Chemistry in Portugal from 1900 to 1970: A contribution to the history of science. Orbital: Electronic Journal of Chemistry 9(5): 363-371.

10. António F da Silva (1900) Primeiros elementos de Chimicaanalytica mineral e orgânica, Tomo I - Analyse qualitativa; Tomo II - Análise quantitativa, $2^{\mathrm{a}}$ edição, Porto. Archives of Faculty of Sciences of Oporto, António Ferreira da Silva file.

11. António F da Silva (1905) Notas sobrea Nomenclatura chimicaportugueza dos elementos, compostos e funções chimicas, Revista Portugueza de Chimica Pura e Applicada.

12. Serafim Gesta, António Ferreira da Silva (1976) sua vida e obra, Centro Revolucionário Mineiro.

13. António Ferreira da Silva (1890) Sur une nouvelle rèaction de la cocaine, Bulletin de la Société Chimique de Paris.

14. António F da Silva (1890) Sur l'emploi du sulfosélénite d'ammoniaque pour caracteriser les alcaloides. Bulletin de la Société Chimique de Paris.

15. António F da Silva (1892) Sur une nouvelle reaction de l'éserine et une matière verte derivèe du même alcaloide, Bulletin de la Société Chimique de Paris.

16. Agostinho A do Souto (1893) O Caso Medico-Legal de Urbino de Freitas, Imprensa Portuguesa.

17. António F da Silva (1900) A questão dos vinhosportugueses no Brasil em 1900, Commercio do Porto.

18. António F da Silva (1896) Sur la constitution des carbonyles métalliques, Bulletin de la Société Chimique de Paris.

19. António F da Silva (1900) Sur la réfraction atomique des metaux dans les carbonyles métalliques et les formules de constitution de ces derivés, Bulletin de la Société Chimique de Paris.

20. António F da Silva (1913) Sur la constitution des dérivés métalliques de l'acétylène, et sur l'acétylène comme lien entre la chimie minérale et la chimie 1organique, Memórias da Academia dei NuoviLincei.

21. Rui Gomes, Ferreira da Silva (2017) 0 primeiroquímico português: fragmentos para umabiografia de António Ferreira da Silva, Guimarães ÓperaOmnia.

22. Serafim Gesta, António Ferreira da Silva (1976) sua vida e obra, Centro Revolucionário Mineiro.
This work is licensed under Creative Commons Attribution 4.0 License

To Submit Your Article Click Here:

Submit Article
AOICS

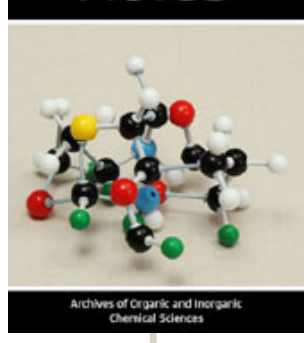

Archives of Organic and Inorganic Chemical Sciences

\section{Assets of Publishing with us}

- Global archiving of articles

- Immediate, unrestricted online access

- Rigorous Peer Review Process

- Authors Retain Copyrights

- Unique DOI for all articles 